\title{
A KINETICS STUDY OF THE HOMOGENEOUS AND HETEROGENEOUS COMPONENTS OF THE HCI + CIONO2 REACTION
}

Randall R. Friedl, Jases H. Goble ${ }^{1}$ and Stanley P. Sander

Jet Propulsion Laboratory, California Institute of Technology

Abstracte The kinetics of the reaction $\mathrm{HCl}+$ $\mathrm{ClONO}_{2}-\mathrm{Cl}_{2}+\mathrm{HNO}_{3}$ were investigated at $298 \mathrm{~K}$ using a flow reactor with FTIR analysis to assess the importance of this reaction for stratospheric chemistry. The observed reaction was characteristic of a heferogeneous process; an upper limit of $5 \times 10^{-18} \mathrm{~cm}^{3}$ molecule $\mathrm{e}^{-1} \mathrm{~s}^{-1}$ was obtalned for the homogeneous gas phase rate constant. From calculations of the first order wall rate constant, estimates were made or the reaction rate on stratospheric aerosols. Because both $\mathrm{HCl}$ and $\mathrm{ClONO}_{2}$ need to be adsorbed on the particle surface, the reaction will be of negligible importance under most stratospheric conditions.

\section{Introduction}

Considerable interest has been focused recentiy on homogeneous and heterogeneous reactions between temporary reservolr spectes in the stratosphere [Dekore et al., 1985; WMO, 1986]. One such reaction,

$$
\mathrm{HCl}+\mathrm{ClONO}_{2} \rightarrow \mathrm{HNO}_{3}+\mathrm{Cl}_{2}
$$

has recelved particular attention because of its large potential 1mpact on the odd chlorine $\left(\mathrm{ClO}_{x}\right)$ budget even at relatively small values of the gasphase reaction rate coefficient $\left(k,>5 \times 10^{-17}\right.$ $\mathrm{cm}^{3}$ molecule-1 $\mathrm{s}^{-1}$ ) [Prather et al., 1984; WHO, 1986 ]. Laboratory studies of this reaction using flow systems [BIrks et al., 1977; Molina et al., 1985] have indicated the presence of a wallcatalyzed component. If the reaction is carried out under conditions which minimize the role of the reactor walls, as in the study of Molina et al. [1985], a very small upper lim1t $\left(k_{1}<1 x\right.$ $10^{-19} \mathrm{~cm}^{3}$ molecule $\mathrm{s}^{-1}$ ) is obtained for the gas phase component of reaction 1 , ruling out any potential stratospherio role for the homogeneous reaction.

The importance of the surface-catalyzed reaction in the stratosphere is more difficult to estimate. Ordinarily, the surface area of the middle stratospheric aerosol is too small for surface reactions of radicals to compete with gas phase processes [HMO, 1986]. Processes which are extremely slow in the gas phase. such as the reactions of $\mathrm{N}_{2} \mathrm{O}_{5}$ and $\mathrm{ClONO}_{2}$ with $\mathrm{H}_{2} \mathrm{O}, \mathrm{H}_{2} \mathrm{O}_{2}$ and HCl, may be enhanced by interactions with surfaces, most notably when the aerosol loading is increased by a mechanisu such as volcanic injection or the formation of polar stratospheric clouds. In particular, Solomon et al. [1986] have suggested that the occurrence of reaction 1 on

\footnotetext{
I Present address: Talandic Research Corporation

Copyright 1986 by the American Geophysical Union.
}

Paper number 6L6331.

$0094-8276 / 86 / 006 \mathrm{~L}-6331 \$ 3.00$ polar aerosols at an equivalent bimolecular rate of $2 \times 10^{-14} \mathrm{~cm}^{3}$ molecule-1 $\mathrm{s}^{-1}$ can help explain the remarkable depletions in the total ozone content in intarctica during the springtime.

In this study, a flow system was used with FTIR analysis to obtain estimates of both the homogeneous and heterogeneous contributions to the rate of the $\mathrm{BCl}+\mathrm{ClOMO}_{2}$ reaction. Calculated wall reaction rates were extrapolated to stratospheric conditions to obtaln lifetimes for the conversion of $\mathrm{ClOHO}_{2}$ to active ohlorine by reaction 1 . It is shown that, even under the most favorable conditions, it is unlikely that the heterogeneous reaction of $\mathrm{BCl}$ with $\mathrm{ClONO}_{2}$ will be an important process in the stratosphere.

\section{Experimental}

The flow reactor consisted of a $61 \mathrm{n}$. dianeter Pyrex tube coupled to a $650 \mathrm{crm}$ Roots blower backed by a 150 ofm meohanical pump. The reactor could also be exhausted to a fume hood for atmospheric pressure operation. The inside surface of the tube was coated with Teflon (DuPont 856200). The opt1cal system consisted of a Bomem DA3.002 Fourler Transform Infrared spectrometer coupled to White-type optics in the rlow tube (150 cm base path, 40 a path length) and a liquid helium-cooled Cu:Ge detector using cooled infrared interference filters.

Kinetic runs were oarried out over the pressure range 1 - 730 torr of helium or nitrogen diluent using a flow veloolty of $10 \mathrm{~cm} \mathrm{~s}^{-1}$. HCl flowed elther from a premixed bulb or directly from the cylinder through an electronic mass flow meter before entering the flow tube. $\mathrm{ClONO}_{2}$ was obtalned by flowing a portion of the carrier gas through a bubbler containing liquid $\mathrm{ClONO}_{2}$ at -78 c. The reagents could be premixed in a short $15 \mathrm{~cm}$ lons, $5 \mathrm{~cm}$ dia. section upstream of the main flow tube, or in the flow tube itself by adding the $\mathrm{ClONO}_{2}$ through a silding injector positioned along the flow tube axis. The reaction conditions were such that HCl was generally in great excess over $\mathrm{ClONO}_{2}$. $\mathrm{HCl}$ concentrations ranged from $5 \times$ $10^{13}$ to $1 \times 10^{18}$ molecule cm $\mathrm{cm}^{-3}$ ClONO concentrations varied from 1 to $20 \times 10^{13}$ molecule $\mathrm{cm}^{-3}$. Reactants and products were analyzed from FTIR scans taken at $0.1 \mathrm{~cm}^{-1}$ resolution. CIONO was monitored in the $v_{2}$ band $\left(^{\mathrm{NO}_{2}}\right.$ symmetric stretch) at $1290 \mathrm{~cm}^{-1}$ while $\mathrm{HNO}_{3}$ was monttored in the $v_{4}$ band ( $\mathrm{NO}_{2}$ symmetric stretch) at $1325 \mathrm{~cm}^{-1}$. Infrared absorbances for $\mathrm{HNO}_{3}$ and $\mathrm{ClONO}_{2}$ were callbrated agalnst ov spectrometric and barometric measurements, respectively.

\section{Resuits}

Experiments were carried out by fixing the flow rate of $\mathrm{ClOHO}_{2}$ at a given total pressure of diluent gas and measuring the integrated $\mathrm{ClOHO}_{2}$ band absorption before and after the addition of $\mathrm{HCl}$. With $\mathrm{HCl}$ present, $\mathrm{ClONO}_{2}$ disappearance and 


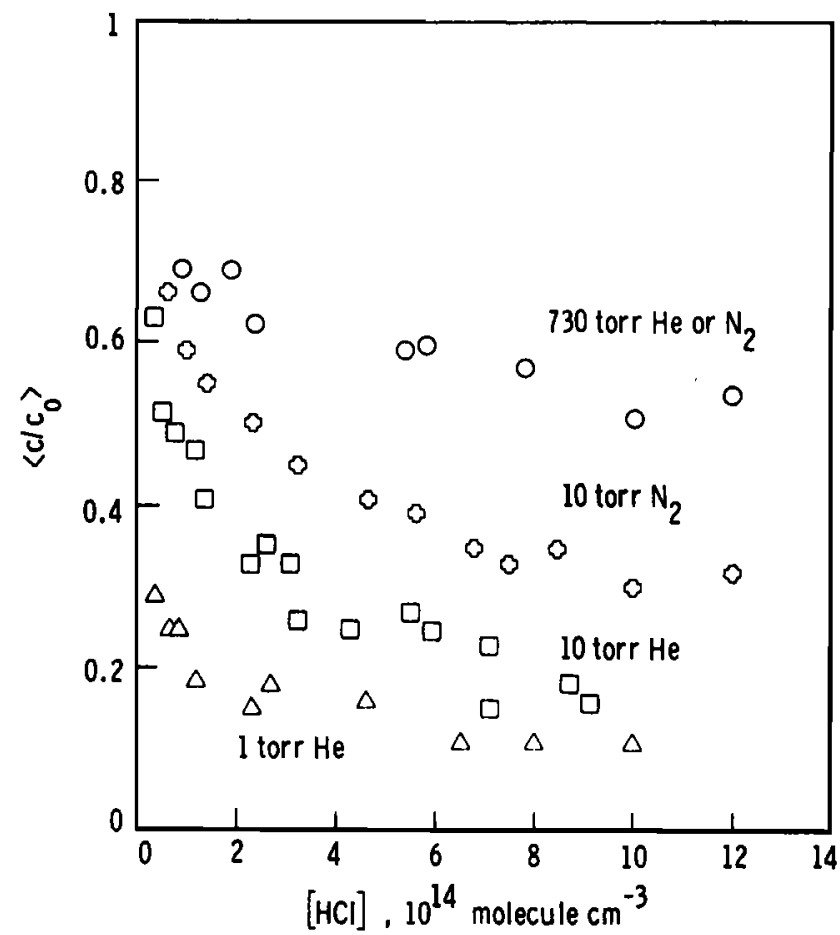

F18. 1. Pressure dependence of the integrated $\mathrm{ClONO}_{2}$ depletion vs. [HCl].

$\mathrm{HNO}_{3}$ formation were observed. Since the optical system integrates the $\mathrm{ClONO}_{2}$ absorption along the flow tube axis, the aeasured depletion is given by

$$
\left\langle\mathrm{c} / \mathrm{c}_{0}\right\rangle \equiv \frac{1}{\left.[\mathrm{ClONO}]_{0}\right]^{\top}} \int_{0}^{l}\left[\mathrm{ClONO}_{2}\right] d z
$$

The dependence of $\left\langle 0 / \mathrm{c}_{0}\right\rangle$ on [HCl] is shown in Figures 1 and 2. From figure 1, it 18 apparent that $\mathrm{ClONO}_{2}$ is quickly depleted with the addition of even the lowest concentrations of HCI but that this removal quickly saturates with increasing HCl. Figure 2 shows the dependence of $\left\langle\mathrm{c} / \mathrm{c}_{0}\right\rangle$ on [HCI] over the range $1 \times 10^{14}$ to $1 \times 10^{18}$ molecule $\mathrm{cm}^{-3}$ at $1 \mathrm{~atm}$. total pressure of $\mathrm{N}$. Above $\mathrm{HCl}$ concentrations of $2 \times 10^{14}$ moleoule $\mathrm{cm}^{-3}$ the dependence of $\left\langle\mathrm{C} / \mathrm{c}_{\mathrm{O}}\right\rangle$ on [HCl] is weak and the presence of high ( $30^{\circ}$ torr) pressures of HCl does not completely remove the chlorine nitrate, which is present in concentrations about $\mathrm{flve}$ orders of magnitude below the BCl. From the data in Figure 2 , an upper 11mit of about $5 \times 10^{-18} \mathrm{~cm}^{3}$ molecule $\mathrm{s}^{-1}$ can be derived for the homogeneous (gas phase) component of reaction 1. The data in Figure 9 also Indicate that the global reaction rate hows a pronounced inverse pressure dependence, 1.e. Increasing diluent gas pressure causes a decrease in rate. Onder conditions of constant reactor residence time (15 s), [ClOHO $]_{0}$ (2 $\times 10^{-13}$ molecule $\mathrm{cm}^{-3}$ ) and temperature (298 $\mathrm{K}$ ), reactivity increases as total pressure decreases in the following order: 730 torr He or $\mathrm{N}_{2}, 10$ torr $\mathrm{N}_{2}, 10$ torr He, 1 torr He.

As indicated in Figure 1 , kinetic runs oarried out under the same conditions produced repeatable results, indicating that the reactivity and adsorption/desorption characteristics of the reactor walls were stable. At each pressure, the quantity $\left[\mathrm{ClONO}_{2}\right]+\left[\mathrm{HNO}_{3}\right]$ was constant. Th1s indicates a) that the total concentration of reactive nitrogen in the system is conserved, b) that no 1mportant product channels have been overlooked and c) that there is no heterogeneous loss of reactive nitrogen.

To better characterize the system, several variations or the $\mathrm{ClONO}_{2}$ depletion experiment were carried out. is a qualitative check on the reactivity of the walls, several runs were performed at 10 torr He with the flow tube lined with 0.5 me thick TFE Terlon sheet. The use of this aterial resulted in nore rapld $\mathrm{ClOMO}_{2}$ renoval then under the corresponding conditions with the Torlon ooating. Several runs were carried out using the flow tube injector to introduce the $\mathrm{ClOMO}_{2}$ several centineters downstream fron the aain oarrier gas injection point, the objective being to ensure thet the flow was laminar before the chealcal reaction could begin. Variation of the Injector position had no effect on the overall resction rate.

\section{Disoussion}

Three features of the kinetic data strongly suggest that the $\mathrm{BCl}+\mathrm{ClONO}_{2}$ reaction is a wallcatalyzed process in this system: 1) the dependence of $\mathrm{ClONO}_{2}$ depletion on added $\mathrm{BCl}$, which 1s characteristic of an adsorption 1sotherm, 2) the inverse dependence of the $\mathrm{ClONO}_{2}$ depletion upon total pressure and 3) the sensitivity of the reaction rate to the wall material. Some insight Into the origin of these features can be obtained by considering the detalls of the simultaneous processes of diffusion and reaction in the flow tube.

For the bimolecular reaction taking place under preudo-first order conditions in the gas phase, the observed loss of $\mathrm{ClONO}_{2}$ is given by

$$
\left\langle c / c_{0}\right\rangle=\frac{v}{k_{1}[\mathrm{HCl}]_{1}}\left(1-e^{-k_{1}[\mathrm{HCl}] 1 / v}\right) g(R)
$$

where $\left\langle c / c_{0}\right\rangle=$ reactant depletion observed by integrating along a tube of length $l, k_{q}=$ bimolecular rate constant for the gas phase reaction, $v=$ flow veloc1ty, $B(R)=\operatorname{rad} 1 a l$ concentration distribution function. The function $g(R)$ allows for the fact that the optical system samples uniformiy coross the tube radius and $\mathrm{ClONO}_{2}$ will, in general, not have a uniform radial distribution due to wail reaction and radial and axial diffusion. For pressures in the 1-10 torr regime, $g(R)$ may be assumed to be unity. Dnder these conditions, it was found that the above relationship could not be fit to the observed dependence of $\left\langle\mathrm{C} / \mathrm{C}_{0}\right\rangle$ on [HCl] suggesting that the

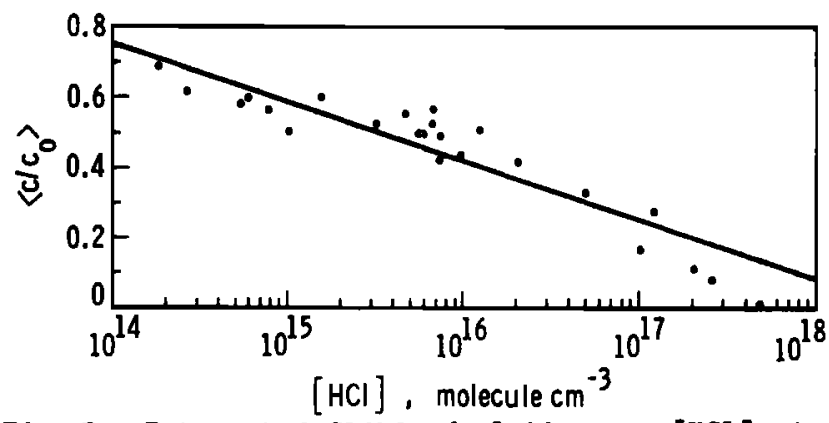

F1g. 2. Integrated $\mathrm{ClONO}_{2}$ depletion vs. [HC1] at 1 atm. total pressure of $\mathrm{N}_{2}$. 


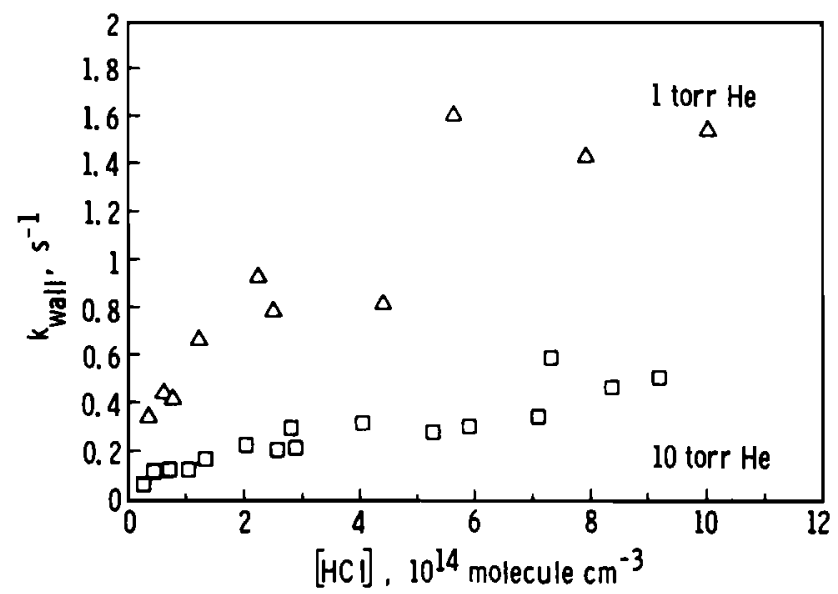

Fig. 3. Pressure dependence of the pseudo firstorder wall reaction rate constant, $k_{\text {wall, }}$ vs. [HCl] computed using the assumption that the homogeneous component of the $\mathrm{HCl}+\mathrm{ClONO}_{2}$ reaction is negligible.

reaction did not proceed by a direct homogeneous gas-phase process.

In order to more fully underatand the effects of diffusion and wall reaction, the continuity equation for fully developed laminar steady state tube flow was applied using the solution of Walker [1961] and the computer algor1thm of Brown [1978]. The results of the flow tube modeling calculations are shown in Figure 3. The wall rate constant, $k_{W}$, has both a pressure dependence between $;$ and 10 tor and a nonlinear dependence on [HC1] over the range $(0.2-10) \times 10^{14}$ molecule $\mathrm{cm}^{-3}$. A dependence on the HCl concentration $1 \mathrm{~s}$ expected based upon the assumption that reaction 1 is a heterogeneous process whose rate depends on the density of reactive surface sites occupied by HCl. The nonlinear dependence on [HCl] Indicates that the surface adsorption isotherm of HCl is approaching saturation in this concentration range. The data at both 1 and 10 torr He suggest that the linear portion of the 1sotherm would manifest itself at $\mathrm{HCl}$ concentrations below about $1 \times 10^{13}$ molecule $\mathrm{cm}^{-3}$.

The computed values of $k_{k}$ display an inverse pressure dependence, deoreasing by about a factor of 4 between 1 and 10 torr of helium. A similar effect was observed by Loewenstein and Anderson [1985] who studied the pressure dependence of the reactions of $\mathrm{OH}$ radicals with $I_{2}$ and $I C l$ in a discharge flow reactor between 1 and 10 torr of He and $\mathrm{Ar}$. They suggested that the diluent gas itself might have exerted a direct effect on $k_{w}$ by occuping some of the active sites. In this study, the reactor surface is not sufficientiy well characterized to model the wall reaction in deta1l. In addition, because of the slow flow velocity (10 cm $\left.\mathrm{s}^{-1}\right)$, axial difrusion is very 1mportant in the 1 torr experiments, and the large correction entalled by this effect also complicates the interpretation of the experiments at this pressure. The results for $k_{y}$ at 10 torr hellum should be somewhat more rellable as the corrections for both radial and axial diffusion are less than 20 per cent under these conditions.

Previous studies of reaction 1 have employed a variety of reactor types which differ in such oharacteristios as total pressure, gaseous transport rate, and surface to volume ratio.
Since these reactor characteristics deteraine the sensitivity of the reactors to wall catalyzed processes, they can account for the large differences in the previously reported upper limfts for $k_{1}$ : Birks et al. [1977] ( $k_{1} \leq 1.2 \times$ $10^{-15} \mathrm{~cm}^{3}$ nolecule $\mathrm{s}^{-1}$, measured in fast- $19 \mathrm{gy}$ apparatus); Mol1ng et al. [1985] (k, $\leq 1 \times 10^{-19}$ ch moleoule $\mathrm{s}^{-1}$, pulsed jet); Hatakeyana and Leu [1986] $\left(k_{1} \leq 8.4 \times 10^{-21} \mathrm{~cm}^{3}\right.$ moleoule $\mathrm{e}^{-1} \mathrm{~g}^{-1}$ static photolysis); th1s work $\left(k_{1} \leq 5 \times 10^{-18} \mathrm{~cm}^{3}\right.$ molecule ${ }^{-1} s^{-1}$, slow-flow).

\section{Implications for Stratospheric Chemlstry}

The upper limits to the value of $\mathrm{k}_{1}$ measured by Molina et al. [1985], Hatakeyama and Leu [1986] and ourselves rule out the possibility of a signiflcant regeneration of active chlorine through this reaction in the gas phase. However, the possibility remains that the reaction can take place heterogeneously on the surface of stratospheric aerosols. The measurement in this study of $k_{y}$ as a function of the gas phase HCl concentration permits an estimate to be made of the stratospheric 11fetime of $\mathrm{ClOHO}_{2}$ under assuned conditions of stratospheric aerosof loading. Such a calculation is necessarily very approximate because of large uncertalnties in the size distribution and catalytic efficiency of the aerosol. There will also be differences between the adsorption 1sotherms and reactivities of the aerosol and the Teflon wall coating of the laboratory reactor. Nevertheless, an order-ofmagnitude estimate will be instructive.

The pseudo-first order rate constant for the disappearance of $\mathrm{ClONO}_{2}$ in the presence of an $\mathrm{HCl}$ coated surface is given by

$$
\mathbf{k}_{\mathbf{w}}=\mathbf{k}_{\operatorname{cot1} \gamma}
$$

where $k_{c 011}$ is the first order collision rate with the surface and $\gamma$ is the reactive collision efflelency. For particles larger than the mean free path, $k_{\text {coll }} w 111$ be proportional to the aerosol surface area per unit volume. $\gamma$ is a function of both the surface $\mathrm{HCl}$ concentration and the intrinsic catalytic properties of the substrate. In the linear portion of the adsorption 1sotherm, the surface HCl concentration will be proportional to [BCI]. In the laboratory system, this regime is encountered under conditions where [HCl] $<1 \times 10^{13}$ molecule $\mathrm{cm}^{-3}$, as indicated in F1gure 2. If it $1 \mathrm{~s}$ assumed that Teflon and atmospheric aerosol surfaces have equivalent adsorption 1sotheras and catalytic properties, the first order heterogeneous rate constant for $\mathrm{ClONO}_{2}$ removal by $\mathrm{HCl}$ in the stratosphere is given by

$$
k_{w}^{a t m}=k_{w}^{l a b} \frac{S_{a t m}}{S_{1 a b}} \frac{[H C l]_{a t m}}{[H C l]_{1 a b}}
$$

where $k_{w}^{\text {lab }}\left(0.1 s^{-1}\right)$ is the observed laboratory rate constant at the reference $\mathrm{HCl}$ concentration, $S_{\text {atm }}$ and $S_{1 \mathrm{ab}}$ are the volumetric surface areas of the atmospheric aerosol and the laboratory reactor, respeotively, [HCl] stratospheric HCl number density ( $189^{\circ}$ moleoule $\mathrm{cm}^{-3}$ ) and [HCl] 1 is the laboratory reference BCl conoentration $\left(10^{13}\right.$ molecule $\left.\mathrm{cm}^{-3}\right)$. Osing a liberal estimate for the surface area of a stratospheric aerosol, $1000 \mathrm{\mu}^{2} \mathrm{~cm}^{-3}$ [Bormann and hosen, 1985], and a value of $2.6 \times 10^{7} \mu^{2} \mathrm{~cm}^{-3}$ for 


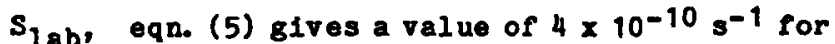
$k_{y}^{a} l^{\prime}$, or a lifetime greater than 1000 years. For comparison with the calculations of solomon et al. [1986], an equiralent bimolecular rate constant for the heterogeneous reaction of $4 \times 10^{-19} \mathrm{~cm}^{3}$ molecule $e^{-1} \mathrm{~s}^{-1}$ can be derived from $k_{w}^{\text {atm. ThIs }}$ bimolecular rate constant is nearly five orders of magnitude smaller than the value required by Solomon et al.

The major uncertainty in this calculation has to do with the extrapolation of $\gamma$ from the laboratory case to the stratospheric situation. At the lower atmospheric temperatures, the adsorption isotherm of HCl will probably shift in the direction of higher surface HCl concentrations, however, the temperature dependence of the rate of surface catalysis is unknown. Overall, the HCl + $\mathrm{ClONO}_{2}$ reaction does not appear to have a large temperature dependence; Molina et al. [1985] observed an 1ncrease in $\mathrm{k}_{\mathrm{w}}^{\mathrm{lab}}$ of less than a factor of 2 as the temperature was decreased from $294 \mathrm{~K}$ to $249 \mathrm{~K}$.

While very approximate, this calculation suggests that the $\mathrm{HCl}+\mathrm{ClONO}_{2}$ reaction will be three to four orders of magnitude too slow to cause any signifleant conversion of reservolr chlorine to the more labile form, $\mathrm{Cl}_{2}$, on a time scale comparable to other reactions of $\mathrm{HCl}$. The reason for this is that both reactants, which are present in trace concentrations in the gas phase, must be adsorbed onto the surface before reaction can take place. In contrast, reactions which take place on aqueous surfaces such as

$$
\begin{gathered}
\mathrm{ClONO}_{2}+\mathrm{H}_{2} \mathrm{O}(\mathrm{s}) \longrightarrow \mathrm{HOCl}+\mathrm{HNO}_{3} \\
\mathrm{~N}_{2} \mathrm{O}_{5}+\mathrm{H}_{2} \mathrm{O}(\mathrm{s}) \longrightarrow 2 \mathrm{HNO}_{3}
\end{gathered}
$$

can proceed considerably faster since the surface substrate plays a role as a chemical reactant.

Acknowledrements. The authors wish to thank Drs. J. J. Margitan, R. A. Stachnik and M. J. Molina for many helpful discussions. The research described in this paper was carried out by the Jet Propulsion Laboratory, California Institute of Technology, under contract with the National Aeronautics and Space Administration.

\section{References}

B1rks, J. W., B. Shoemaker, T. J. Leck, R. A. Borders, and L. J. Hart, Studies of reactions of importance in the stratosphere. II.
Reactions involving chlorine nitrate and chlorine dioxide, If Cheme Physe, 66, 4591$4599,1977$.

Brown, R. L., Tubular reactors with first-order

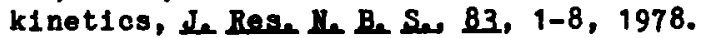

DeMore, H. B., J. J. Margitan, M. J. Molina, R. T. Watson, D. M. Golden, R. F. Hampson, M. J. Rurylo, C. J. Howard, and A. R. Rav1shankara, Chemlcal kinetics and photochemical data for use in stratospheric modeling, evaluation no. 7. JPL Publication 85-37, Jet Propulsion Laboratory, Pasadena, Calif., 1985.

Hatakeyama, S., and M.-T. Leu, Reactions of Chlorine Nitrate with $\mathrm{HCl}$ and $\mathrm{H}_{2} \mathrm{O}$, Geophys. Hese Letter this issue.

Hormann, D. J., and J. M. Rosen, Antarctic observations of stratospherlo aerosol and high altitude condensation nuclel following the El Chichon eruption, Geophyse Bese Lett. $12,13-16,1985$.

Loewenstein, L. M., and J. G. Anderson, Rate and product measureaents for the reactions of $O H$ with $I_{2}$ and ICl at $298 \mathrm{~K}$ : Separation of gasphase and surface reaction components, I. Phys, Cheme, 89, 5371-5379, 1985.

Molina, L. T., M. J. Molina, R. A. Stachnik, and R. D. Tom, An upper $11 \mathrm{mit}$ to the rate of the HCl + ClOHO reaction, de Physe cheme, Bg, 3779-3781, 1985.

Prather, M. J., M. B. McElroy, and S. C. Wofsy, Reductions in ozone at high concentrations of stratospheric halogens, Mature, 312, 227-231, 1984.

Solomon, S., R. R. Garcla, F. S. Rowland, and D. J. Wuebbles, on the depletion of Antarctic ozone, Nature, 321, 755-758, 1986

Halker, R. A., Chemical reaction and diffusion in a catalytic tubular reactor, Phys, Eluids, 10. 1211-1216, 1961.

World Meteorological Organization, Atmospheric Ozone 1985: Assessment of our understanding of the processes controlling its present distribution, WHe report no. 16, Washington D.C., 1986.

R. R. Friedl, S. P. Sander, M/S 183-301, Jet Propulsion Laboratory, 4800 Oak Grove Dr., Pasadena, California 91109.

J. H. Goble, Taland1c Research Corp., 2793 E. Footh1ll Blvd., Pasadena, California 91107.

(Recelved August 15, 1986; accepted August 21, 1986) 